\title{
A Framework and Evaluation Technique for Project's Viability of Privatization Highway Projects in Malaysia
}

\author{
Azmi Mohamed ${ }^{1}$, Zakaria Mohd Yusof ${ }^{\# 2}$, Sarajul Fikri Mohamed ${ }^{3}$,Mohd Saidin Misnan", \\ Rashidul Islam ${ }^{5}$ \\ ${ }^{1}$ Quantity Surveying \& Contract Branch, Malaysian Highway Authority (LLM), \\ Jalan Serdang-Kajang, 43000 Bandar Baru Bangi, Selangor, Malaysia \\ 2,3,4,5 Department of Quantity Surveying, Faculty of Built Environment, \\ Universiti Teknologi Malaysia, Skudai 81310, Johor Bahru, Johor, Malaysia \\ 1.azmi@llm.gov.my,,2b-zyusof@utm.my,, ${ }^{3}$ sarajul@utm.my,, b-saidin@utm.my,, mrislam1080@gmail.com \\ \#Corresponding Author e-mail: b-zyusof@utm.my
}

\begin{abstract}
The construction sector is one of the indicators of national economic growth and has contributed 4\% yearly in average to Malaysia GDP and 6\% to the national economy between 1995 - 2015. The excellent of construction growth is mainly from projects implemented under "Public-Private Partnership" (PPP) and privatization. Under $10^{\text {th }}$ Malaysian Plan, 52 projects valuing about RM62.7 billion will be implemented under PFI for infrastructure works. This study aims to evaluate the project viability and the correlation between the costs and revenue collected for entirely concession period. A systematic framework for project viability of highway privatization projects has been developed based on research findings. The methodology adapted in this research is by using descriptive literature technique analysis. The research finding shows that most preferred technique used by respondents are Internal Rate of Return (IRR) and Net Present Value (NPV). In sustaining the highway projects, the costs incurred during concession period should be managed efficiently. Four (4) variables are found for evaluating project's viability and identifying which variables correlate and significantly contributes to the project viability namely operation cost, maintenance cost, actual toll traffic, and revenue. Actual traffic volume significantly correlates with the revenue meanwhile the operation cost is less correlated to the revenue. This research highlighted the viability of the privatized highway projects for entirely concession period and based on the findings, it is suggested a comprehensive framework for future project evaluation comprising of 8 components of commercial and technical evaluation for privatization highways in Malaysia need to be introduced and recommended to be implemented in the industry.
\end{abstract}

Keyword - Public-Private Partnership (PPP), Life Cycle Costing (LCC), Viability, Highway Project

\section{INTRODUCTION}

Malaysia is a multi-racial and multi-religious country in South East Asia with a population of about 27 million people and a land area of 329,613 square kilometres. It is an economically successful country with encouraging economic and physical growth and development [1]. The period between 1995 to 2015 also saw a boom time for the Malaysian construction industry. It has recorded a growth of an average $4 \%$ annually and contributed about $6 \%$ to the national economy [2] and provided nearly 1 million jobs to Malaysians so much so it was dubbed as "the engine of growth" of the country [3].

Many have suggested that the encouraging economic growth of the country since 1985 was attributed to the privatization strategy and policy launched in 1983, two years after it was announced by the Prime Minister. To formalize the policy, the Economic Planning Unit of the Prime Minister Department produced a "Guideline on Privatization" in 1985. Later, in 1991, it published the "Privatization Master Plan". In the Seventh Malaysia Plan (1991-1995) the privatization programmed has been accelerated and efforts have been made to strengthen the implementation process and procedures [4]. The privatization programmed continued in the Eighth Malaysia Plan and by the 9th and 10th Malaysia Plans it became an important machine of growth for the country. According to [5], by the end of 9th Malaysia Plan (2006 - 2010), almost 514 nos. privatized and PPP projects in the transport, roads and highway, communication, health and energy sectors have been established (7MP, 8MP, 9MP). In the Tenth Malaysia Plan (2011 - 2015) 52 more projects valuing about RM62.7 billion were implemented under the privatization and public-private partnership initiatives [7].

The privatization program launched by the Government includes the privatization of roads and highways construction throughout the country. It started with the construction of North Klang Straits Bypass (NKSB) in 1983 which was undertaken by Shapadu Company Ltd. It was followed by the construction of the Jalan Kuching Highway by Kamunting Corporation Ltd. In 1986. 
After the successful completion of the North-South Expressway in 1987, several more toll highways have been constructed. These include the, Kesas Highway, Elite Highway, Linkedua Highway and Penang Bridge. By 2012, the total length of toll highways, federal roads, and state roads in Malaysia is 150,872.17 km (HPU, KKR, 2012). Out of these, 28 highways with a total length of about 1,731.1 km are privatized toll highways (MHA, 2012). In year 2014, a total length of privatized toll highways is $1,798 \mathrm{~km}$ have been constructed and thus ranking Malaysia as one of the best in Southern Asia, the third after China and Japan and fifth in the world in terms of highway construction and networking.

\section{THE OBJECTIVES OF HIGHWAY PRIVATIZATION}

As stated in the Privatization Master Plan 1995, the main objectives of the Government's Privatization Policy are to relieve the financial and administrative burden of the Government, to facilitate economic growth and to help meet the national development targets

Meanwhile, the aim and objectives of the road and highways privatization policy have also been drawn to complement those stated in the Privatization Master Plan. The objectives of the highway privatization are as follows:

a. Efficient use of resources, saving of government funds.

b. Reduce financial burden and risk from the privatization of the construction, management, maintenance and operation of highways.

c. The capital facilities to be more effectively and economically designed, constructed.

d. Better travelling facilities, accident and emergency services, and

e. Significant reduction of travelling time.

At the same time, a review of the terms and conditions on the concession contracts brought to light not only the rights and obligations of the parties such as government and the concession company, but also the scope and nature of services or facilities to be provided by the concession companies under the contract.

\section{PRIVATIZATION OF HIGHWAY PROJECTS IN MALAYSIA}

Privatization is one of the private finance initiative (PFI) or public private partnership (PPP) models that have been widely applied for civil engineering works including highway projects. The concept of PFI, later known as PPP, was introduced in Malaysia in the Fourth Malaysia Plan 1981s [6]. Under the PFI/PPP scheme, a special purpose vehicle (SPV) from the private sector is generally responsible to design, build, finance, and operate a public project for twenty to thirty years [8].

Privatizationis the process of transferring an enterprise or industry from the public sector to the private sector. The public sector is the part of the economic system that is run by government agencies. Privatization may involve either sale of government-held assets or removal of restrictions that prevent private individuals and businesses from participating in each industry. Privatization is an ongoing trend in many parts of the developed and developing world.

The term privatization has alternate meanings within business and finances. According to [9], the main reason to opt privatization for implementing the government projects because the private sector is claimed to have more skills and expertise to efficiently design, construct, operate and maintain the projects. Meanwhile, the Government will facilitate and monitor the progress of the PPP projects. The time saving can be used to focus more on the administrative side and on how to better serve the public [10]. Privatization can also be defined as the transfer of ownership, property, or business from the government to the private sector [9].

PFI can be defined as a method of providing funds for major capital investments where private firms are contracted to complete and manage public projects. Under a private finance initiative, the private company, instead of the government, handles the up-front costs. Most PFI projects are involved with risks, hence it is necessary to balance the risks and rewards of public and private sectors in PFI projects and should be done at the early stage of the projects. A commonly accepted principle is to allocate risks to the party best able to manage it at least cost [11].

The Government had been introduced a comprehensive planning and implementation for infrastructure project such as road/highway and other civil engineering projects within a 5-year National Development Plan (Rancangan Malaysia - RMK). Historically, in 1970, the Government had introduced a New Economic Policy which are included RMK2 - RMK5 based on the First Outline Perspective Plan (OPP1; 19780 - 1990).

Based on a comprehensive plan by Government, subsequently the Second Outline Perspective Plan (OPP2: 1991 - 2000) was formulated to strengthen the road planning and development. This second plan introduced is to formulate the framework to guide national development for the first decade of Vision 2020 under the National Development Policy which was replaced the NEP. The focus in OPP2 are to improve road network that linkages urban and inter urban and to alleviate of transport problems with the rapid urbanization of major towns. As resulted, the existing roads and construction of ring roads in the RMK6 and RMK7 were constructed. 
The overall development roads under RMK7 was guided by the Highway Network Development Plan (HNDP 2020). The total length of road constructed up to RM7 had increased to 65,000km. To achieve a developed country by 2020, the Government had adopted the Third Outline Perspective Plan (OPP3: 2001 2010) which objective to develop of infrastructure projects and amenities to support the growth of economic activities in the less developed states will be accelerated.

Based on New Economic Policy (NEP), under RMK2 and RMK3, the toll highways in Malaysia took in placed with the establishment of Malaysia Highway Authority (MHA), Ministry of Works which was approved by Parliament under Act 231 in 1980. The objective of the MHA's establishment is to construct, maintain and operate toll highway projects in Malaysia. The government planned and mooted the First Malaysia Plan (RMK1 - 1966 - 1970) until the current 11MP (2016 - 2020) in strengthening infrastructures including roads and highways.

In 1977, the federal Government decided to embark on the construction of a toll expressway from Bukit Kayu Hitam to Johor Bahru in Johor as a package of highway privatization. It involved the taking over of $350 \mathrm{~km}$ of the North-South highway which had been constructed by the Malaysian Highway Authority (MHA) It is now known as the North-South Expressway or PLUS highway. After the successful completion of the North-South Expressway in 1987, several more toll highways have been introduced in this plan, namely, Kesas Highway, Elite Highway, Linkedua Highway and Penang Bridge.

According to MHA,2012 total length of privatized toll highway $1731.1 \mathrm{~km}$ and in 2014 increased to $1798 \mathrm{~km}$. In 2016, five more highway projects are being constructed under the privatization and PPP programmed. They are Damansara-Shah Alam Expressway (DASH), Sungai Besi-Ulu Kelang Expressway (SUKE), Duta-Ulu Kelang Extension (DUKE2), Kuala Lumpur-Putrajaya Extension (MEX2), West Coast Expressway (WCE) and East Kelang Valley Expressway (EKVE).

\section{VIABILITY OF PRIVATISED HIGHWAY CONSTRUCTIONS}

The privatization of highway projects is not a straightforward process to implement. Many criteria must be considered, and compromise must be made to find a sustainable and viable project. According to [12], many criteria must be considered for a project to be viable and sustainable. The criteria are project cost effectiveness, economic viability and environmental impact, safety improvement, optimized mobility, and accessing and preserving of the existing structure.

Economic feasibility is one of the most important assessments in ascertaining that a project would be successful and viable. The literature indicates several factors to be considered in implementing a project. [13] states that from economic feasibility aspect, analyzed on a "total project" basis, all the costs should be computed into the analysis to reflect the overall economic viability of the project.

A project viability study is an in-depth investigation of the profitability of the construction project and it states outcome of a project must be prudent and profitable comparing with its associated cost, time, quality, and manpower requirement. The conventional measures or the so-called iron triangle of time, cost, and quality has been the dominating performance indicator in construction projects [14]. The project is considered an overall success if the project meets the technical performance specifications and/or missions to be performed, and if there is a high level of satisfaction is present [15].

There are a lot of factors to determine the project viability. Project viability mainly depends on various factors such as technical analysis, financial analysis, economic analysis, management, experience, past performance, organization, health and safety, quality, resources and ecological analysis [15]. They conclude that proper financial analysis is the most important factor and must lie with the other factors. On the financial aspect, a financial analysis is used to analyze whether a business is financially stable, solvent, liquid, or profitable enough to be invested in.

The literature also indicates that for every fiscal year during the operation period, the cash flow model annually calculates all the revenue and expenditures of the project. At the end of the operation period, the performance metrics calculation model is utilized to determine the financial viability of the PPP highway project investment. The development of the model is shown below Fig. 1 [16].

The authors [17]concluded in their research that the data of financial analysis cover total project costs, means of finance, and the cost of finance and operating that is resulted from the life of the projects.

The following techniques have been used to measure or evaluate return of investment:
a. $\quad$ Net present value (NPV)
b. Accounting rate of return (ARR)
c. Internal rate of return (IRR)
d. Modified internal rate of return
e. Adjusted present value 

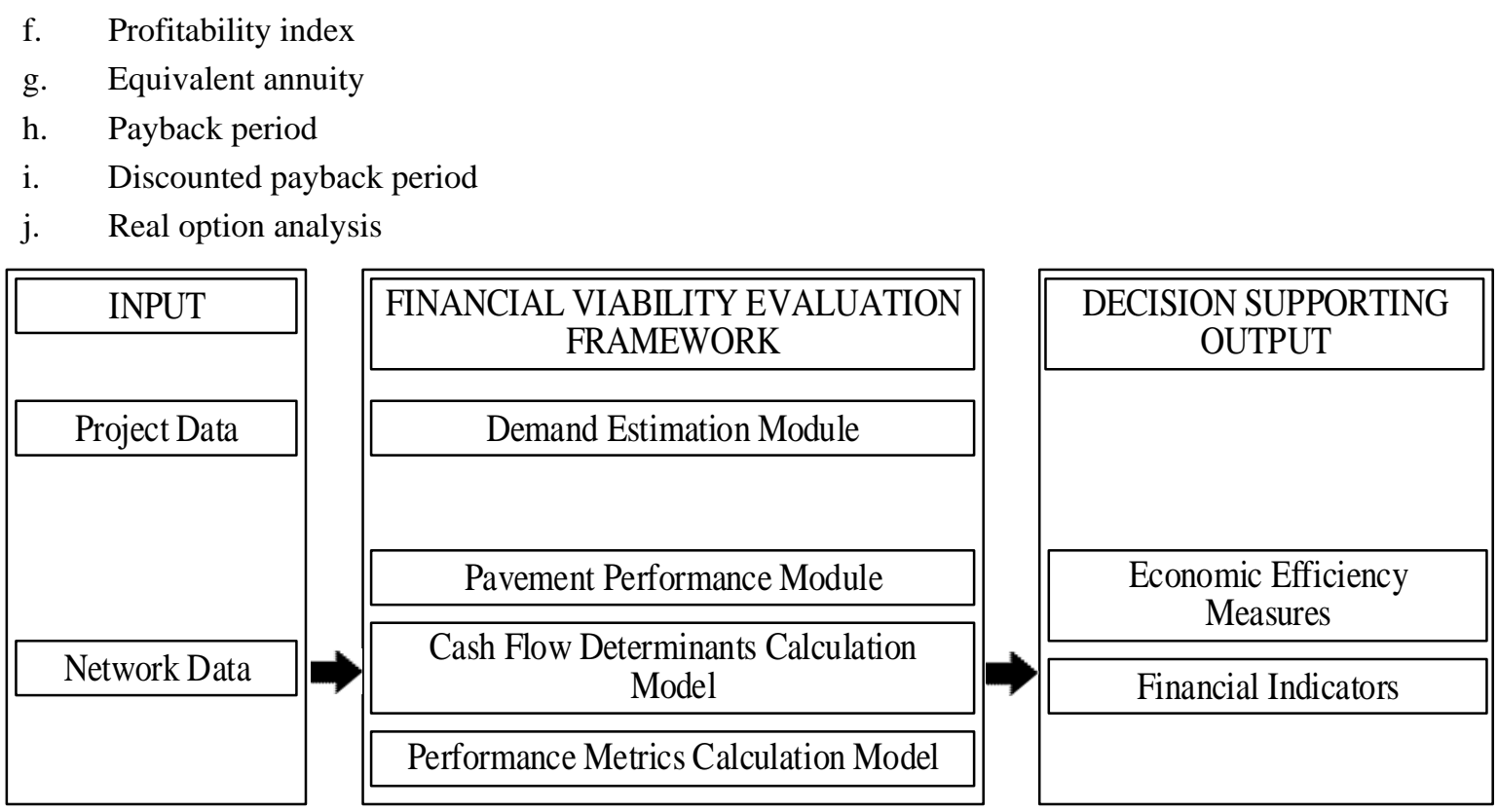

Fig. 1. Development model for project viability

Nevertheless, the most common methods used by investors and business organizations have been the net present value method (85\%), the return of capital employed method (15\%), the internal rate of return method (56\%), and the payback period method (53\%).

Operation and maintenance costs are among the several life-cycle costs involved in running and preserving a project. Today, we are drawn to the concept and application of value management for securing value for money for the design and construction of large multi-million-ringgit construction projects. The literature on life cycle costing and life cycle cost analysis suggest that life cycle costing analysis provide much data and information needed by the stakeholders of an investment. The required information are as follows capital cost including repayment cost, repair and maintenance cost, operating cost, management cost, disposal cost.

The above costs can be computed as the total cost of the facility over its life at current value or as an annual cost over the whole life of the facility, i.e. projected cash flow at net present value. According to the [16], the most common methods for assessing financial viability of a project are accounting the rate of return, payback period, net present value (NPV,) and internal rate of return (IRR). These methods were found to be able to assess the financial viability of a project.

The LCCA has been increasingly used as an evaluation technique in value management by private and public agencies in the US and UK, especially in evaluating investment in construction facilities. It is said that LCCA can generate data and information pertaining to the following:

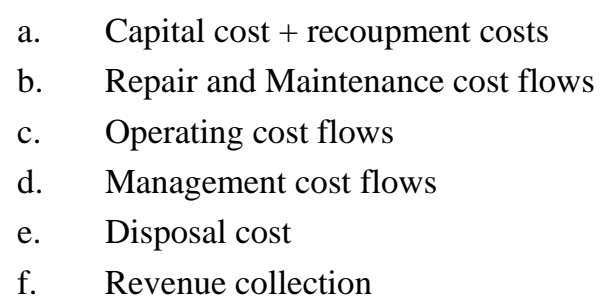

The output of the LCC/LCCA are cost and financial information which are normally presented in projected cost flow format. They are prudently computed by considering the changing value of money over the specified period based on the concept of net present value of money, annual sinking fund, and projected compound interest. [18] mentioned that LCCA is an evaluation technique that shows the significant and relevant annual cost over a period in the form of cost flow. It is a projected cost flow that will help to define the levels of performance of investment in terms of economy, efficiency, effectiveness, and equity, i.e. value for money.

It was recorded that the number of highway privatizations in Malaysia had been increased from time to time. The increased number of privatized highway projects implies that the projects have brought about good return and could be sustained within a concession period. The literature indicates that the traffic volume has increased from $4 \%$ to $5 \%$ every year. This implies that the increase of the number of traffic volume will gain more toll collections for the company. 


\section{LIFE CYCLE COSTING IN HIGHWAY PROJECTS}

The technique for estimating the overall cost of an asset is referred to as Life Cycle Cost (LCC). The estimation of cost and it management over the LCC of an asset are important aspects of every project which are crucial to it success [19]. The financial fate of a project can be easily determined from its initial cost estimate, projects more often do experience cost overrun due to inaccurate estimates and poor management. LCC which is commonly used in construction projects is the life cycle costing (LCC), whole life costing (WLC) or some may call it life cycle cost analysis (LCCA). In the earlier days, it was called the "cost-in-use technique". It is one of the techniques used in value management exercise to assess the value of an asset over its entire life.

LCC is a very useful approach for estimating the total cost incurred all through an asset's life time, this includes the initial cost acquisition, it installation, maintenance, operation, renovation, and to it final disposal cost $[20,24]$. [21] describe the LCC of an asset as "the total cost of that asset over its operating life, including the initial acquisition costs and subsequent running costs". [22] equates the LCC of an asset as "the present value of total cost of the asset over its operating life, including initial capital costs, occupation costs, operating costs, and the cost or benefit of the eventual disposal of the asset at the end of its life".

The concept of LCC does not only focus on costs but also the revenue accrued during the productive life of a project. LCC is the subset of WLC as illustrated in Fig. 2.

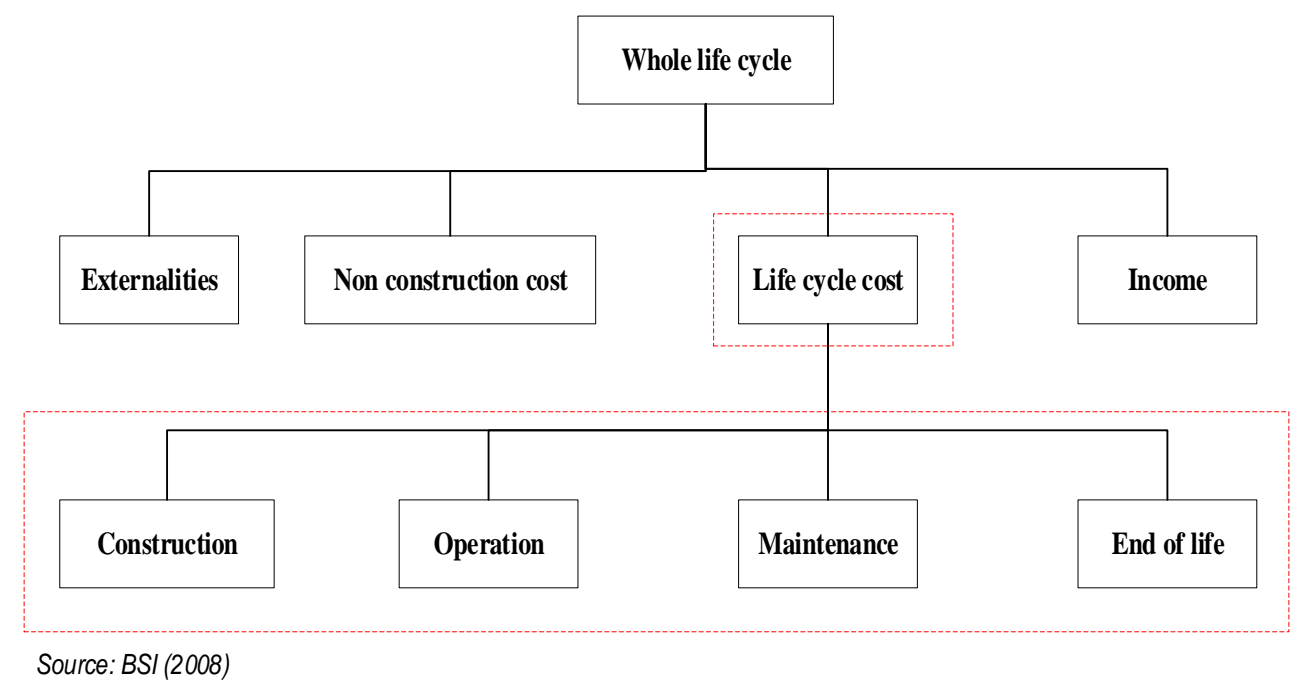

Fig. 2. Concept of LCC (source: BSI 2008)

It is very important to note that a project should be evaluated very thoroughly to get good return. The viability and economically of the project should be assessed and evaluated in stages at the initial stage towards project completion. Many projects failed due to the wrong decision made by the company and client. Feasibility study is an evaluation technique that can facilitate decision making. The main criterion that normally influences decision making is "finance" [23]. A good "finance administered" can make good returns of investment.

LCC of an asset can be done at any point in time of the asset's life cycle. The decisions regarding the facility installation, design, manufacturing, support, operations, and disposal can be made using LCC inputs (results). Fig. 3 illustrates the factors that need to be considered in calculating LCC in order to make it the project sustainable and viable for the entirely period. These factors were project life span, project financing and interest rate imposed by banker, design life of assets to be maintained (component of life span) and obsolescence to the assets during life span. These factors are most important to be considered in calculating LCC for sustainability and viability of the projects. 


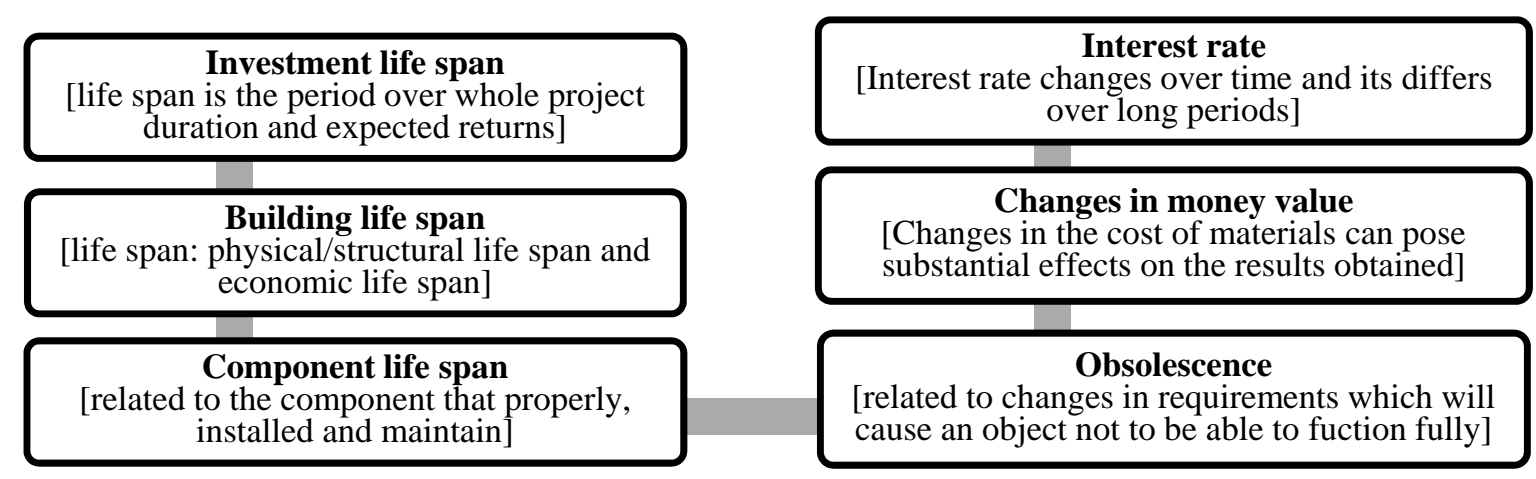

Fig. 3. Factors needs to be considered in calculating LCC

As mentioned earlier, from the various techniques of evaluating viability of the projects, the most common used are IRR and NPV. The projected future revenue of a project's present value is determined using NPV calculations. The present value of the project cost is deducted in the calculation from its present value of future income. A project will be implemented or accepted if the NPV is positive, and rejected if it is negative. It is difficult to project the revenue of a project with exact precision as the project might experience negative cash flow whereas the projection was positive cash flow.

One of the merit of IRR technique is that, the timing of the future revenue and cost are taking into consideration when doing the calculation. The time value of money for each year cash flow is been given same weight. The IRR method can also be used for decision making purpose to control budget (e.g. either to purchase new equipment or repair the old one). IRR also has its demerits. One of it demerit is that when comparison is done between projects, the sizes of the projects are not taken into consideration. Another disadvantage of IRR is that it ignores reinvestment rates.

\section{FRAMEWORK FOR HIGHWAY PROJECTS}

In terms of the costs incurred (operation and maintenance) or spent by concession company during operating years are very huge to operate the highways and to make project sustain and profitability, the concession company need to closely monitor with efficiently. These variables will have affected the project viability as well.

As mentioned earlier, to evaluate the viability and profitability of the highway projects, four (4) variables were used namely operation cost, maintenance cost, actual traffic volume, and revenue. From the literature analysis, actual traffic volume and revenue were the most significant variables that had contributed to the profit of the project.

Based on LCC calculation, using a reasonable NPV and IRR, the project viability can be assessed based on the 'project break even' within the concession period.

It is suggested that the framework of project viability for privatization highway projects need to be developed and ascertained based on most significant variables that contributed to the viability such as high traffic volume, reasonable project cost, reasonable toll rate, achievable project IRR and the whole concession period given by government to the concession company. 


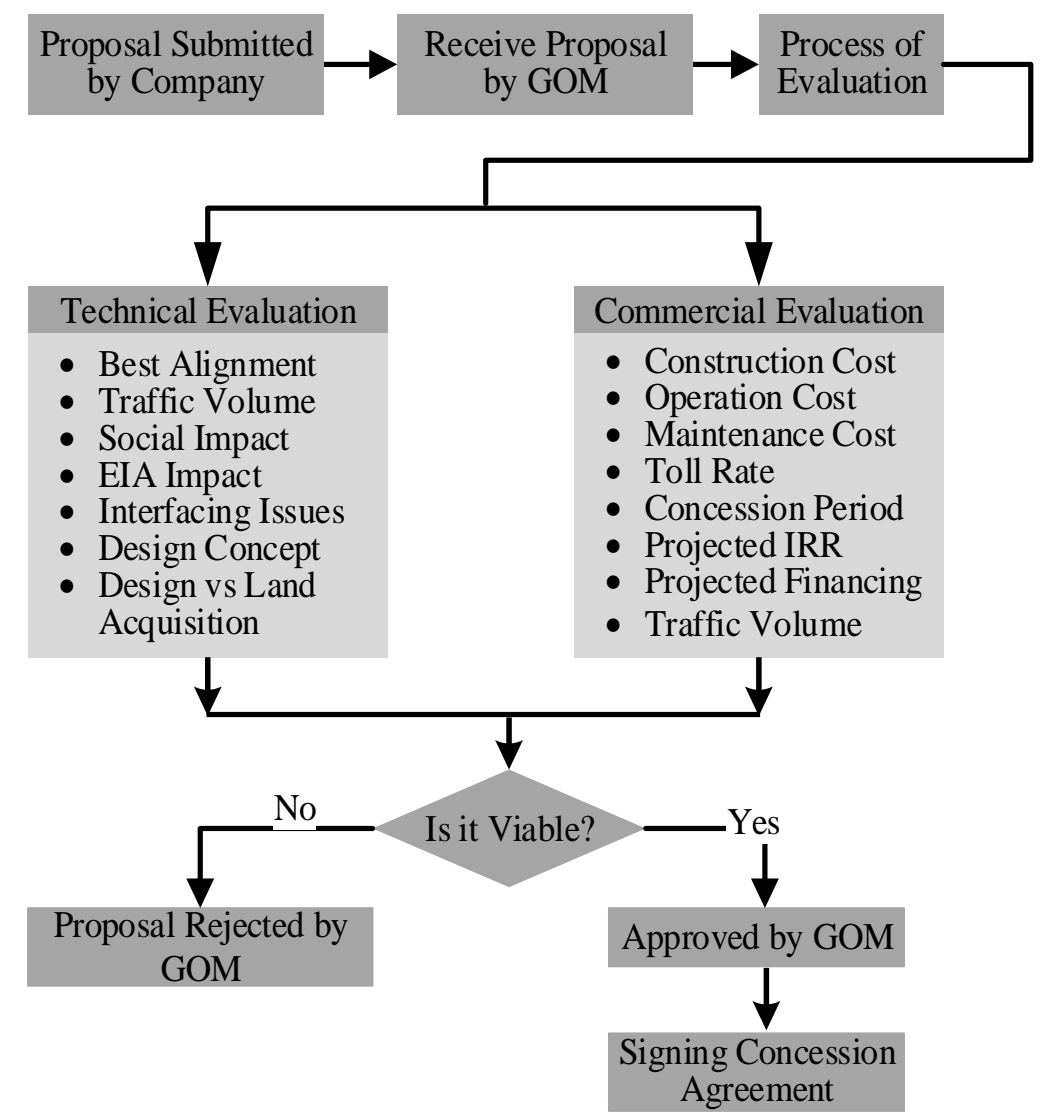

Fig. 4. Project viability evaluation frameworkt

Fig. 4 shows that the process of evaluation of project's viability of the highway privatization in Malaysia. According to Lembaga Lebuhraya Malaysia (2013), there are two areas of evaluation will be performed to ensure that the proposed highway is viable. These two areas are commercial evaluation and technical evaluation. Financial viability evaluation is key component to evaluate project viability in PPP highway project investment [16]. In addition, [23] revealed that highway project type, indexed cost, geographic location and project delivery method are the key attributed need to be considered as technical evaluation.

\section{A. TechnicalEvaluation}

The technical evaluation is most on the compliance on the design requirements and to follow all the guidelines administered by the Government agencies. For instance, the alignment proposed should be free from any encumbrances, minimize the EIA impact and social impact, to avoid interfacing issues with the other authorities, and the most important part is the design of the mainline of the highways vs. land acquisition to be paid by the Government. In other words, the design should be designed accordingly to minimize the cost of land to be acquired and to make sure that the land cost paid by the Government is optimum and economical.

\section{B. Commercial Evaluation}

The commercial evaluation has some parameters that need to be accessed. The assessment of the commercial parameters includes project cost (including construction, operation and maintenance cost), projected traffic volume, propose toll rate, projected project IRR, concession period and project financing are critical factors that will contribute to the viability of the projects.

For the cost of operation and maintenance, the company should calculate the current escalation factor and NPV for entirely concession period. The items of operation and maintenance cost should be listed details through work breakdown structure (WBS). The escalation factor and NPV used for operation and maintenance cost should be calculated accordingly to make sure the project cash flow is accurate, achievable, acceptable and reasonable to achieve a good project return.

Project financing is one of the important parameter that need to access very deep. The company propose a proposal shall be a strong company which has a strength financial capability and expertise of the project. Current situation indicated that the company who submitted the project proposal did not strong enough to raised project funding from the lenders/bankers. From this situation, in make it projects viable, the Government should fund the project based on government funding assistant 
Toll rate basically calculated with the formula. Formula of calculating toll rate is based on the costs incurred by the company and the forecasted traffic volume derived. Traffic volume is a most significant factor to contribute to the project viability. Traffic volume is vital and acted as nucleus to sustain the viability of the project for entirely concession period.

\section{CONCLUSION}

This research proposed strategies to bridge privatization and PFI knowledge gap in highway project management. Furthermore, this research also highlighted on the importance of investment method analysis knowledge for the involved company in this industry, also revealed the barriers that can be referred by related parties to start on focused in bridging the gap. Moreover, this study developed a practical framework to demonstrate the strategic actions and potential effects related to each factor.

The framework of project viability for privatization highway projects can be determined and ascertained based on most significant variables that contributed to the viability such as high traffic volume, construction cost, operation cost, maintenance cost, reasonable toll rate, achievable project IRR, project financing, and the whole concession period given by government to the concession company. The developed framework can be implemented in the any privatized highway project in Malaysia to improve of existing process of evaluating the viability of the project. The learnings from this conducted research can deliver a good source of references for research practitioners and professionals in other countries.

This study was conducted on the only privatized highway projects in Malaysia. Next, this research was focused on the profitability of the privatized and PFI aspect that has a strong connection with the issue of knowledge and knowledge management. Nevertheless, the knowledge level was not within the scope of this research.

\section{REFERENCE}

[1] Mydin, M. O., Salim, N. A., Tan, S. W., Tawil, N. M., \& Ulang, N. M. “Assessment of significant causes to school building defects”, In E3S Web of Conferences,EDP Sciences, vol. 2, 2014.

[2] Alaloul, W. S., Liew, M. S., \& Zawawi, N. A. "Identification of coordination factors affecting building projects performance”,Alexandria Engineering Journal, vol. 55, no. 3, pp. 2689-2698, 2016.

[3] Khan, R. A., Liew, M. S., \& Ghazali, Z. B. "Malaysian construction sector and Malaysia vision 2020: Developed nation status”,Procedia-social and behavioural sciences, vol. 109, pp. 507-513, 2014.

[4] Myeda, N. E., \& Pitt, M. “Facilities management in Malaysia: Understanding the development and practice”. Facilities, vol. 32, no. 910, pp. 490-508, 2014.

[5] Mohd-Noor, N., Hamid, M. Y., Abdul-Ghani, A. A., \& Haron, S. N. "Building maintenance budget determination: an exploration study in the Malaysia government practice”. Procedia Engineering, vol. 20, pp. 435-444, 2011.

[6] Ismail, S. "Critical success factors of public private partnership (PPP) implementation in Malaysia". Asia-Pacific Journal of Business Administration,vol. 5, no. 1, pp. 6-19, 2013.

[7] Ismail, S. "Drivers of value for money public private partnership projects in Malaysia”. Asian Review of Accounting,vol. 21, no. 3,pp. 241-256, 2013.

[8] Meng, X., \& McKevitt, N. J. "Improving the bankability of a PFI financing application”. The Journal of Structured Finance,vol. 17, no. 3, pp. 78-87, 2011.

[9] Ismail, S., \& Azzahra Haris, F. “Constraints in implementing public private partnership (PPP) in Malaysia”. Built Environment Project and Asset Management, vol. 4, no. 3, pp. 238-250, 2014.

[10] Burger, P., \& Hawkesworth, I. "How to attain value for money: comparing PPP and traditional infrastructure public procurement". OECD Journal on Budgeting, vol. 11, no. 1, pp. 91, 2011.

[11] Hwang, B. G., Zhao, X., \& Gay, M. J. S. "Public private partnership projects in Singapore: Factors, critical risks and preferred risk allocation from the perspective of contractors". International Journal of Project Management, vol. 31, no. 3, pp. 424-433, 2013.

[12] Ziari, H., Behbahani, H., \& Ali Amini, A. "A Framework for Economic Evaluation of Highway Development Projects Based on Network-Level Life Cycle Cost Analysis”. PROMET-Traffic \& Transportation, vol. 27, no. 1, pp. 59-68, 2014.

[13] Diaz, C. E. D. "A Framework for Determining the Viability of Public-Private Partnerships for Toll Road Projects in the Philippines”. Journal of the Eastern Asia Society for Transportation Studies, vol. 8, pp. 174-186, 2010.

[14] Toor, S and Ogunlana, S. O. "Beyond the 'iron triangle': Stakeholder perception of key performance indicators (KPIs) for large-scale public-sector development projects”. International journal of project management, vol. 28, no. 3, pp. 228-236, 2010.

[15] Alzahrani, J. I., \& Emsley, M. W. "The impact of contractors' attributes on construction project success: A post construction evaluation”,International Journal of Project Management, vol. 31, no. 2, pp. 313-322, 2013.

[16] Jeerangsuwan, T., Said, H., Kandil, A., \& Ukkusuri, S. "Optimization application for financial viability evaluation of PPP toll road projects”. In Construction Research Congress 2012: Construction Challenges in a Flat World., pp. 2329-2338, 2012.

[17] Waghmare, A. P., \& Pimplikar, S. S. "Financial Analysis of Infrastructure project-A Case Study on Built-Operate-Transfer Project in India”. International Journal of Engineering and Advanced Technology (IJEAT) ISSN; pp. 2249-8958, 2012.

[18] Perera, O., Morton, B., \& Perfrement, T. "Life Cycle Costing: A Question of Value: A White Paper from IISD”. International institute for sustainable development. 2009.

[19] Odendaal, M. M. "The estimation and management of cost over the life cycle of metallurgical research projects" (Doctoral dissertation). University of Pretoria. 2012.

[20] Heralova, R. S. "Life cycle costing in the preparation of public works contracts". International Scientific Conference People, Buildings and Environment, pp. 15-17, 2014.

[21] Flanagan, R., Norman, G., \& Meadows, J. “Life cycle costing: theory and practice”. BSP Professional Books. 2012.

[22] Hoar, D., \& Norman, G. "Life cycle cost management”. Quantity surveying techniques: new directions. Oxford: Blackwell Scientific, pp. 139-168, 1990.

[23] Ahmad, K. H. Construction Economics: Problems and Solutions. Pearson Malaysia. 2012.

[24] Khiyon, N.A. and Mohamed, S.F. "Life Cycle Costing of Mechanical and Electrical Services for Private Finance Initiatives Projects in Malaysia”. International Journal of Tomography \& SimulationTM, vol. 28, no. 3, pp.96-103, 2015. 